\title{
A strategy for the clinical remission of acute lymphoblastic leukemia elicited by treatment of $\beta$-thalassemia major: A case report
}

\author{
MIGUEL A. PALOMO-COLLI ${ }^{1}$, MARTA ZAPATA-TARRES ${ }^{2}$, OSVALDO D. CASTELÁN-MARTÍNEZ ${ }^{3}$, \\ LUIS E. JUÁREZ-VILLEGAS ${ }^{1}$ and LOURDES P. CÓRDOVA-HURTADO ${ }^{4}$ \\ ${ }^{1}$ Department of Oncology, Hospital Infantil de México Federico Gómez, Mexico City 06720; \\ ${ }^{2}$ Department of Pediatric Oncology, Instituto Nacional de Pediatría, Mexico City 04530; \\ ${ }^{3}$ Facultad de Estudios Superiores Zaragoza, Universidad Nacional Autónoma de México, Mexico City 09230; \\ ${ }^{4}$ Department of Hematology, Hospital Infantil de México Federico Gómez, Mexico City 06720, Mexico
}

Received September 5, 2017; Accepted November 13, 2017

DOI: $10.3892 / \mathrm{mco} .2017 .1533$

\begin{abstract}
Acute lymphoblastic leukemia (ALL) has been suggested as a long-term complication in patients with $\beta$-thalassemia major ( $\beta$-TM). A 12 -months-old male patient was diagnosed with $\beta$-TM. The patient required a blood transfusion weekly for 2 years. At the age of 4 years, a splenectomy was performed due to massive splenomegaly and frequent transfusion requirements. The histopathological analysis of the spleen revealed extensive hemosiderosis. ALL-L1 with the $\mathrm{T}$ immunophenotype and without central nervous system (CNS) involvement was diagnosed when the patient was 5 years old, and treated with anti-leukemic combination chemotherapy and CNS radiotherapy. The patient completed 24 months of treatment and has been in complete remission for 7 years, without long-term adverse events.
\end{abstract}

\section{Introduction}

$\beta$-thalassemia comprises a group of hereditary hematological disorders characterized by abnormalities in the synthesis of the $\beta$ chains of hemoglobin, resulting in variable phenotypes, ranging from severe anemia to clinically asymptomatic individuals. Patients with $\beta$-thalassemia major ( $\beta$-TM) usually present with severe anemia within the first 2 years of life,

Correspondence to: Dr Miguel A. Palomo-Colli, Department of Oncology, Hospital Infantil de México Federico Gómez, 162 Dr Márquez Street, Col. Doctores, Cuauhtémoc, Mexico City 06720, Mexico

E-mail:phalomi@gmail.com

Abbreviations: $\beta$-TM, $\beta$-thalassemia major; $\mathrm{RBC}$, red blood cell; ALL, acute lymphoblastic leukemia; CBC, complete blood count; CNS, central nervous system

Key words: acute lymphoblastic leukemia, child, Mexican, $\beta$-thalassemia major, iron overload requiring regular red blood cell (RBC) transfusions (1). However, transfused patients may develop complications associated with iron overload. Chelation therapy increases patient survival; however, long-term complications include cancer development (2). $\beta$-TM is rare among Mexican pediatric patients (3). By contrast, acute lymphoblastic leukemia (ALL) is the most common type of cancer in Mexican children (4,5). Several genetic factors are associated with increased risk of ALL, but the majority of the patients have no identified inherited factors $(6,7)$. Previous studies suggested that ALL may develop as a long-term complication of $\beta$-TM treatment (8-10), although the association between these two hematological diseases has not been fully elucidated. We herein describe a case of remission of T-cell ALL in a Mexican male patient with $\beta$-TM and analyze clinical data and the association between these two pathologies.

\section{Case report}

A 9-month-old male infant, with no known European ancestry, presented in August 2003 to the community hospital with anemia and jaundice. The patient received iron and folic acid supplementation, without improvement of the symptoms. At the age of 1 year, the patient received an RBC transfusion and was referred to a third-level pediatric hospital located in Mexico City due to increased abdominal girth. Upon physical examination, the patient was found to have cervical lymphadenopathy, splenomegaly extending to the lower left quadrant, and hepatomegaly crossing the umbilicus.

The patient's initial complete blood count (CBC) was as follows: Hemoglobin (Hb) $7.9 \mathrm{~g} / \mathrm{dl}$, hematocrit $25.8 \%$, mean corpuscular volume $88.6 \mathrm{fl}$, mean corpuscular hemoglobin $27.1 \mathrm{pg}$, mean corpuscular hemoglobin concentration $30.6 \%$, and platelet count $91,000 / \mathrm{mm}^{3}$. The patient's blood type was $\mathrm{O}$ positive. The reticulocyte count was $23 \%$, the fetal $\mathrm{Hb}$ was $2.58 \%$ and $\mathrm{HbA} 2$ was $8.87 \%$. The bone marrow aspirate exhibited increased cellularity with normal megakaryocytes, promyelocytes $(2 \%)$, myelocytes $(18 \%)$, juveniles $(9 \%)$, bands $(13 \%)$, segments $(6 \%)$, eosinophils $(5 \%)$, monocytes $(0.5 \%)$, 
Table I. Comparison between reported cases of ALL in $\beta$-TM patients.

Patients (Refs.)

\begin{tabular}{|c|c|c|c|c|c|}
\hline & No. 1 (1) & No. 2 (2) & No. 3 (2) & No. 4 (3) & Present case \\
\hline Sex/age, years & $\mathrm{M} / 8$ & $\mathrm{~F} / 9$ & $\mathrm{M} / 3.5$ & $\mathrm{M} / 9$ & $\mathrm{M} / 5$ \\
\hline Nationality & Greek & Iranian & Iranian & Egyptian & Mexican \\
\hline ALL immunophenotype & - & B-cell & B-cell & B-cell & T-cell \\
\hline $\begin{array}{l}\text { Maintenance treatment } \\
\text { of } \beta \text {-TM }\end{array}$ & Blood transfusion & $\begin{array}{l}\text { Blood } \\
\text { transfusion }\end{array}$ & $\begin{array}{l}\text { Blood } \\
\text { transfusion }\end{array}$ & Blood transfusion & $\begin{array}{l}\text { Folic acid, blood } \\
\text { transfusion }\end{array}$ \\
\hline Chelation therapy & - & DFO & None & DFO, DFX & DFO \\
\hline Hydroxyurea therapy & - & - & - & No & No \\
\hline Age at $\beta$-TM diagnosis & 4 years & 6 months & 3 years & 12 months & 12 months \\
\hline Treatment & $\begin{array}{l}\text { Chemotherapy, } \\
\text { cranial radiotherapy }\end{array}$ & - & - & Chemotherapy & $\begin{array}{l}\text { Chemotherapy, } \\
\text { CNS radiotherapy }\end{array}$ \\
\hline Prognosis & $\begin{array}{l}\text { CR, } 7 \text { months' } \\
\text { follow-up }\end{array}$ & - & - & $\mathrm{CR}, \mathrm{MP}$ & $\begin{array}{c}7 \text { years in } \\
\text { complete remission }\end{array}$ \\
\hline
\end{tabular}

ALL, acute lymphoblastic leukemia; $\beta$-TM, $\beta$-thalassemia major; CR, complete remission; DFO, deferoxamine; DFX, deferasirox; CNS, central nervous system; MP, maintenance phase.

lymphocytes (43.5\%) and plasma cells (2.5\%); based on these findings, $\beta$-TM was diagnosed. Treatment was started with folic acid, ascorbic acid and transfusion therapy. RBC transfusions (10-15 ml/kg/week) were required for 2 years. The iron profile was as follows: Iron, $70 \mu \mathrm{g} / \mathrm{dl}$; iron-binding capacity, $192 \mu \mathrm{g} / \mathrm{dl}$; free iron, $122 \mu \mathrm{g} / \mathrm{dl}$; saturation, 36.4\% and ferritin, $1,900 \mathrm{mg} / \mathrm{ml}$. Six months later, chelation with deferoxamine was started at a dose of $40 \mathrm{mg} / \mathrm{kg}$. At the age of 4 years, splenectomy was performed due to massive splenomegaly and frequent transfusion requirements. The resected spleen weighed $1,000 \mathrm{~g}$ and histopathological analysis revealed extensive hemosiderosis. One month later, the patient presented with diarrhea and meningitis treated with cefotaxime and vancomycin for 14 days. During the meningitis episode, the patient developed seizures and was treated with phenytoin $(6.2 \mathrm{mg} / \mathrm{kg} / \mathrm{day})$ for 2 years.

At the age of 5 years and 8 months, the patient presented with infiltrative syndrome and hepatomegaly. CBC showed the following results: $\mathrm{Hb}, 12.8 \mathrm{~g} / \mathrm{dl}$; leukocytes, $90,500 / \mathrm{mm}^{3}$; and platelets, $263,000 / \mathrm{mm}^{3}$. ALL-L1 with a $\mathrm{T}$ immunophenotype and without CNS involvement was diagnosed. The patient then developed tumor lysis syndrome (TLS) manifesting with nausea, vomiting, hyperuricemia and hyperphosphatemia. TLS was treated with intravenous liquids $\left(3,000 \mathrm{ml} / \mathrm{m}^{2}\right)$, alkalization (bicarbonate $50 \mathrm{mEq} / \mathrm{l}$ ) and alopurinol $\left(300 \mathrm{mg} / \mathrm{m}^{2}\right)$. Dexamethasone therapy (6 $\mathrm{mg} / \mathrm{m}^{2} /$ day) was initiated, and the patient responded well. Remission induction was started with vincristine, L-asparaginase, daunorubicin, dexamethasone, and triple intrathecal chemotherapy. The patient developed pancreatitis and septic shock (Escherichia coli) after the second dose of L-asparaginase. The patient was treated according to St. Jude Children's Research Hospital protocol for high-risk ALL. In addition, prophylactic cranial radiotherapy (18 Gy) due to hyperleukocytosis of cells with the T immunophenotype $\left(78,000 / \mathrm{mm}^{3}\right)$. The patient completed 24 months of treatment and chemotherapy has been electively discontinued, without long-term adverse events. The patient's age at present is 16 years and has been in complete remission for 7 years (last follow-up, August 2017). The patient and his parents consented to the publication of the clinical case details.

\section{Discussion}

To date, there have only been reports of pediatric cases with $\beta$-TM who developed ALL with the B immunophenotype (Table I). To the best of our knowledge, this is the first report of ALL with the $\mathrm{T}$ immunophenotype in a child previously diagnosed with $\beta$-TM. In the previous cases, the majority of the patients were male. Similarly, other reports indicated that boys with thalassemia are more likely to develop hematological malignancies compared with girls $(11,12)$. In all the cases, the emergence of ALL occurred within 6 months to 8 years after $\beta$-TM treatment was initiated. Collectively, these observations suggest that a side effect of $\beta$-TM treatment is ALL occurrence, which adversely affects the patient's prognosis. Iron overload resulting from prolonged transfusions has been considered to be carcinogenic, as it has the ability to damage biomolecules, leading to the production of hydroxyl radicals and other reactive oxygen species that induce a wide array of DNA lesions, from base modifications to strand breaks and adducts (13). Additionally, iron accumulation has been shown to induce DNA hypermethylation. The AIEOP group reported that $\beta$-TM is the most common genetic disease in ALL patients, excluding Down's syndrome (14). Furthermore, the children of women who received iron supplementation pregnant were more likely to develop ALL [odds ratio $(\mathrm{OR})=1.36,95 \%$ confidence interval (CI):1.14-1.63] compared with the children of mothers who were not prescribed iron supplements (15). In this respect, it has been hypothesized that childhood ALL is frequently initiated by a chromosomal translocation event in utero, and iron may provide a proliferative advantage to leukemic cells, 
thus driving disease progression (16). This suggests that children with $\beta$-TM developing ALL may be born with mutations, and iron contributes to the development of leukemia. In addition, Kennedy et al demonstrated that genetic variants of the transferrin receptor gene (TRFC, rs733655; OR=2.6, 95\% CI: 1.44-4.70) are associated with ALL in non-Hispanic white males, further supporting the hypothesis that iron excess mediated by genetic variants increases the risk of childhood ALL (17). However, the majority of patients with $\beta$-TM and ALL received chelation therapy. Moreover, Quattrin et al reported a similar incidence in leukemia between thalassemia patients and the general population (18). Furthermore, $\beta$-thalassemia patients not requiring $\mathrm{RBC}$ transfusions also develop hematological malignancies, including ALL, indicating that the simultaneous occurrence of these diseases may be coincidental $(12,19)$.

Of note, evidence indicates an association between T-cell ALL and preexisting ataxia-telangiectasia (AT), reflecting a non-random mechanism of leukemogenesis $(14,20)$. In this regard, ATM gene truncating mutations were 12.9 times more frequent in childhood T-cell ALL compared with the normal population $(\mathrm{P}=0.004)(21)$. Patients with these pathologies have a poor prognosis. The patient in the present case did not have AT. This report adds to the evidence suggesting an association between $\beta$-TM and ALL.

\section{References}

1. Galanello R and Origa R: Beta-thalassemia. Orphanet J Rare Dis 5: 11, 2010.

2. Russo A and Schilirò G: Thalassemia major and malignancies. Am J Hematol 24: 111-112, 1987.

3. Ruiz-Argüelles GJ, López-Martínez B and Ruiz-Reyes G: Heterozygous beta-thalassemia: Not infrequent in mexico. Arch Med Res 32: 293-295, 2001.

4. Pérez-Saldivar ML, Fajardo-Gutiérrez A, Bernáldez-Ríos R, Martínez-Avalos A, Medina-Sanson A, Espinosa-Hernández L, Flores-Chapa Jde D, Amador-Sánchez R, Peñaloza-González JG, Alvarez-Rodríguez FJ, et al: Childhood acute leukemias are frequent in mexico city: descriptive epidemiology. BMC Cancer 11: 355, 2011.

5. Rivera-Luna R, Shalkow-Klincovstein J, Velasco-Hidalgo L, Cárdenas-Cardós R, Zapata-Tarrés M, Olaya-Vargas A, Aguilar-Ortiz MR, Altamirano-Alvarez E, Correa-Gonzalez C, Sánchez-Zubieta F, et al: Descriptive epidemiology in mexican children with cancer under an open national public health insurance program. BMC Cancer 14: 790, 2014.

6. Hunger SP and Mullighan CG: Acute lymphoblastic leukemia in children. N Engl J Med 373: 1541-1552, 2015.
7. Buitenkamp TD, Izraeli S, Zimmermann M, Forestier E, Heerema NA, van den Heuvel-Eibrink MM, Pieters R, Korbijn CM, Silverman LB, Schmiegelow K, et al: Acute lymphoblastic leukemia in children with down syndrome: A retrospective analysis from the ponte di legno study group. Blood 123: 70-77, 2014.

8. Lau B, Eife R and Lampert F: Acute lymphoblastic leukemia after tuberculosis in a 8-year old greek boy with homozygous beta-thalassemia (author's transl). Klin Padiatr 187: 357-360, 1975 (In German).

9. Naderi M, Miri-Moghaddam E, Alizadeh S, Dorgalaleh A and Tabibian S: Acute lymphoblastic leukemia in two patients with $\beta$-thalassemia major. Zahedan J Res Med Sci 16: 50-51, 2014.

10. Sherief LM, Kamal NM, Abdelrahman HM, Hassan BA and Zakaria MM: First report of acute lymphoblastic leukemia in an Egyptian child with $\beta$-thalassemia major. Hemoglobin 39: 127-129, 2015.

11. Benetatos L, Alymara V, Vassou A and Bourantas KL: Malignancies in beta-thalassemia patients: A single-center experience and a concise review of the literature. Int $\mathrm{J}$ Lab Hematol 30: 167-172, 2008.

12. Otrock ZK, Shamseddine AI and Taher AT: Non-Hodgkin disease in beta-thalassemia major. Am J Hematol 81: 62-64, 2006.

13. Prá D, Franke SI, Henriques JA and Fenech M: Iron and genome stability: An update. Mutat Res 733: 92-99, 2012.

14. Ziino O, Rondelli R, Micalizzi C, Luciani M, Conter V and Aricò M: Acute lymphoblastic leukemia in children with associated genetic conditions other than Down's syndrome. The AIEOP experience. Haematologica 91: 139-140, 2006.

15. Bonaventure A, Simpson J, Ansell P, Roman E and Lightfoot T: Prescription drug use during pregnancy and risk of childhood cancer-is there an association? Cancer Epidemiol 39: 73-78, 2015.

16. Wiemels JL, Cazzaniga G, Daniotti M, Eden OB, Addison GM, Masera G, Saha V, Biondi A and Greaves MF: Prenatal origin of acute lymphoblastic leukaemia in children. Lancet 354: 1499-1503, 1999.

17. Kennedy AE, Kamdar KY, Lupo PJ, Okcu MF, Scheurer ME, Baum MK and Dorak MT: Examination of HFE associations with childhood leukemia risk and extension to other iron regulatory genes. Leuk Res 38: 1055-1060, 2014.

18. Quattrin N, Mastrobouni A, Laudisio FL, Brancaccio V and Pagnini D: Hb Lepore and (haemo-) blastomata. Folia Haematol Int Mag Klin Morphol Blutforsch 103: 915-919, 1976.

19. Tuğcu D, Karakaş Z, Gökçe M, Ağaoğlu L, Unüvar A and Sarıbeyoğlu E, Akçay A and Devecioğlu O: Thalassemia intermedia and acute lymphoblastic leukemia: Is it a coincidental double diagnosis? Turk J Haematol 31: 311-312, 2014.

20. Schütte P, Möricke A, Zimmermann M, Bleckmann K, Reismüller B, Attarbaschi A, Mann G, Bodmer N, Niggli F, Schrappe M, et al: Preexisting conditions in pediatric ALL patients: Spectrum, frequency and clinical impact. Eur J Med Genet 59: 143-151, 2016.

21. Liberzon E, Avigad S, Stark B, Zilberstein J, Freedman L, Gorfine M, Gavriel H, Cohen IJ, Goshen Y, Yaniv I and Zaizov R: Germ-line ATM gene alterations are associated with susceptibility to sporadic T-cell acute lymphoblastic leukemia in children. Genes Chromosomes Cancer 39: 161-166, 2004. 